Article

\title{
Climate Change, Mining and Traditional Indigenous Knowledge in Australia
}

\author{
Tony Birch
}

Moondani Ballak Indigenous Unit, Victoria University, Melbourne, VIC 8001, Australia; E-Mail: Anthony.Birch@vu.edu.au

Submitted: 4 September 2015 | Accepted: 21 January 2016 | Published: 23 February 2016

\begin{abstract}
Australia, in common with nations globally, faces an immediate and future environmental and economic challenge as an outcome of climate change. Indigenous communities in Australia, some who live a precarious economic and social existence, are particularly vulnerable to climate change. Impacts are already being experienced through dramatic weather events such as floods and bushfires. Other, more gradual changes, such as rising sea levels in the north of Australia, will have long-term negative consequences on communities, including the possibility of forced relocation. Climate change is also a historical phenomenon, and Indigenous communities hold a depth of knowledge of climate change and its impact on local ecologies of benefit to the wider community when policies to deal with an increasingly warmer world are considered. Non-Indigenous society must respect this knowledge and facilitate alliances with Indigenous communities based on a greater recognition of traditional knowledge systems.
\end{abstract}

\section{Keywords}

Australia; climate change; indigenous knowledge; interconnection; two-way learning; wellbeing

\section{Issue}

This article is part of the issue "Social Inclusion and Indigenous Peoples", edited by Pat Dudgeon (University of Western Australia, Australia), Waikaremoana Waitoki (University of Waikato, New Zealand), Rose LeMay (Wharerātā Group, Canada) and Linda Waimarie Nikora (University of Waikato, New Zealand).

(C) 2016 by the author; licensee Cogitatio (Lisbon, Portugal). This article is licensed under a Creative Commons Attribution 4.0 International License (CC BY).

\section{Slow Violence}

In Reports from a Wild Country: Ethics for Decolonisation (2004), Deborah Bird Rose writes that 'Settler societies are built on a dual war: a war against Nature and a war against the natives.' From the early years of European occupation of Indigenous Country in Australia, both land and the environment have been degraded by a multitude of forces underpinning colonization, including key aspects of agricultural practice (Muir, 2014), and mining (Altman \& Martin, 2009). Historically, development in Australia has come at the expense of Indigenous wellbeing to the advantage of a society born out of colonial exploitation:

Wealth creation for most Australians has been predicated on expropriation of Aboriginal lands, initially for agriculture and then also for mining from the nineteenth century. (Altman, 2009, p. 17)

The history of colonial expansion is a key contributor to climate change (Lewis \& Maslin, 2015; Weizman \& Sheikh, 2015), producing catastrophic economic and social impacts on Indigenous communities. Recent scholarship also links climate change to wider concerns of human rights and economic and social justice (Green, 2014; Klein, 2014; Nixon, 2011; Shue, 2014). Greater recognition of the knowledge maintained within Indigenous communities relative to localized ecologies and the affects of climate change would go some way to addressing injustice by configuring Indigenous people globally as valuable arbiters of change rather than the helpless victims of the First World:

When considering climkleinate change, indigenous peoples and marginalized populations warrant par- 
ticular attention. Impacts on their territories and communities are anticipated to be both early and severe due to their location in vulnerable environments.... Indigenous and marginalized peoples, however, are not just victims of climate change. Their accumulated knowledge makes them excellent observers of environmental change and related impacts. (Degawan \& Krupnik, 2011)

During the recent United Nations Paris climate change conference, the Canadian prime minister, Justin Trudeau, requested that the formal recognition of Indigenous rights be included in the final accord document (Prystupa, 2015). Both his, and the position of Indigenous activists attending the Paris gathering were undermined by representatives of the United States, the EU and Australia (amongst others) in order to safeguard against any resultant "legal liabilities" to Indigenous communities (although the specifics of such liabilities were not outlined-“Climate talks", 2015). Recalcitrant First World attitudes such as this need change, and with a sense of urgency.

Prior to his removal as prime minister of Australia in September 2015, Tony Abbott had adopted a conservative, or even regressive approach to climate change. The absence of an assertive policy let alone genuine action on climate change met strong criticism. The Commonwealth's formal statement, presented in its 2015 energy paper (Australian Government, 2015a), was poorly received by institutions with relevant expertise. The chief executive of Australia's Climate Institute, John Connor, noting that the energy paper documented "the risk Australia's fossil fuel industry posed in an emissions constrained future", concluded that the report produced no substantial policy to deal with an increasingly unstable climate, leaving Connor to conclude that the report was dominated by a troubling "fantasy of climate ignorance" (Cox, 2015). In a similar criticism, Lenore Taylor, political editor for the Australian arm of Britain's Guardian newspaper, commented that in the months prior to the release of the energy paper the Commonwealth had relied on little more than a "rhetorical smokescreen" to deflect criticism of its inaction on climate change, observing that government policy had been advanced no further in the energy paper itself. She further noted that the Intergenerational Report (Australian Government, 2015b), released around the same time as the energy paper, and being "supposedly an economic and planning document for the next 40 years" was "largely silent on the economic consequences of climate change" (Taylor, 2015a).

The government faced scrutiny at a national and international level over its position on climate change and environmental policy more generally. The eminent Australian scientist and Nobel laureate, Peter Doherty, criticized the government during an international symposium on sustainability held in Hong Kong earlier in
2015. He labeled the Australian government "public enemy number one" with regard its carbon emissions policy (or lack of it). He also attacked the government over an absence of productive negotiations with other nations on climate change (Davey, 2015). This is an alarming conclusion considering that the renowned climate researcher, Professor Will Steffen, of the independent Climate Council of Australia, wrote in the Council's most recent report, Quantifying the Impact of Climate Change on Extreme Heat in Australia, that 2013 had been Australia's hottest year on record; a situation, he concluded, that would have been "virtually impossible without climate change" (Steffen, 2015, p. 1). While the new Prime Minister, Malcolm Turnball, is regarded as being somewhat 'friendlier' to the environment, thus far he has not shifted government policy on climate change. He recently approved the controversial 'mega' Carmichael coal mine in Queensland (Taylor, 2015b), even though multinational mining companies, including BHP Billiton and Rio Tinto are "quietly exiting coal" (Grigg, 2015) and its value to the Australian community, in both an economic and environmental sense is heavily contested (Cleary, 2015). Turnball's position on climate change is also under question due to the Australian government's refusal to sign a joint communique at that Paris summit, to phase out fossil fuel subsidies (Coorey, 2015).

While Australia's searing summer heat has historically produced catastrophic weather events such as the Victorian Black Saturday bushfires of 2009, resulting in 173 direct deaths, Steffen reminds us that 'more Australians die every year from extreme heat than from any type of natural disaster' (such people, often the elderly and the sick, are likely to die from respiratory illness and disease, heart failure and other conditions bought on by heat exhaustion and dehydrationSteffen, 2015, p. 2). Although deaths resulting from heat associated conditions largely escape the eye of media headlines, they represent a strain on general wellbeing in the community and a prohibitive cost to the health system. In the future heat exposure will cause many more deaths than bushfires. If we do need reminding, billions of people will live with climate change in the future and suffer injustice as a result (Green, 2014; Jeromack, 2014; Shue, 2014).

Indigenous communities in Australia are particularly vulnerable to a range of impacts of climate change that threaten the cultural, spiritual, physical and general wellbeing within communities:

Because land and sea are inextricably linked with Indigenous cultural identities, a changing climate threatens ceremony, hunting practices, sacred sites, bush tucker and bush medicine, which in turn affects law, home, health, education livelihood and purpose. (Van Neerven, 2015) 
Potential disruptions will include restricted access to traditional land and sacred sites, the destruction of the sites themselves, and threats to traditional food supplies, which will in-turn deplete health regimes (Green, King, \& Morrison, 2009; Stacy \& Tran, 2013; Tran, Strelein, Weir, Stacy, \& Dwyer, 2013). What is true for Indigenous communities in Australia is reflected in communities in the elsewhere, be it rising sea levels affecting Indigenous communities in both the southern and northern hemispheres. For instance, the Hope (Tikigaq) of Alaska, have been witnessing rising sea levels since the 1970s. They now face the consequence of the negative impacts of climate change on the spiritual, social and economic maintenance of the community (Sakakibara, 2009). A particular injustice suffered by Indigenous people (and the poor more generally), as a direct result of climate change, is evident in the telling irony that "ironically and tragically, climate change is being experienced by many indigenous communities that have not participated in the industrial activity that is its primary cause" (Alexander et al., 2011).

The "slow violence" caused by environmental debilitation, including that wrought by climate change has inflicted harm on the disadvantaged, including Indigenous communities, by wealthier nations and their acts of collective irresponsibility:

The environmentalism of the poor is frequently catalyzed by resource Imperialism inflicted on the global South to maintain the unsustainable appetites of rich-country citizens and, increasingly, of urban middle-classes in the global South itself (Nixon, 2011, p. 17).

The precarious socio-economic status of Indigenous communities within Australia will become exacerbated under climate change, considering that many communities live in a perilous state of disadvantage. While the majority of Australians escaped the ravages of the global financial crisis of 2007 and 2008, Indigenous communities then and now, exist within a cycle of poverty. In 2013 the United Nations ranked Australia second in the world behind only Norway in its annual Human Development Index, a key indicator of physical and social well-being (United Nations, 2013). Unfortunately, had the Index been applied to Indigenous people in Australia alone, it is estimated that the ranking would dramatically slip down the "happiness" ladder to $122^{\text {nd }}$ place (Georgatos, 2015).

It is widely accepted by scientists that an increase in temperature of around two degrees Celsius will cause not only widespread death as a direct result of illnesses and diseases attributed to climate change, but severe mental illness and deep psychological scaring (Christoff, 2014; Hamilton, 2013; Kolbert, 2014). Indigenous people, particularly those living outside major urban centers, will additionally face the consequence of sick- ness to country itself. The ability to adequately engage with Country, to nurture and maintain cultural ceremony for both Elders and the young (Green, King, \& Morrison, 2009) will become increasingly difficult. Indigenous communities live interdependently with country. Sickness, in its holistic cultural, physical and psychological sense will be acutely felt:

A connection with "Country" - a place of ancestry, identity, language, livelihood and community-is a key determinant of health. If community-owned country becomes "sick" through environmental degradation, climate impacts, or inability of traditional owners to fulfil cultural obligations, through the ongoing management and habitation of their land, the people of that land will fell this "sickness" themselves. (Green et al., 2009, p. 1)

\section{Cash over Country}

In addition to the stresses of climate change, Indigenous communities across Australia deal with the impacts of large-scale mining, often targeting fossil fuels, particularly coal. The extraction technologies themselves burn excessive amounts of petroleum-based fossil fuels, releasing additional carbon into the atmosphere (Union of Concerned Scientists, 2015). Australia's reliance on coal, as both an export mineral and in the delivery of a domestic energy supply adds significantly to global carbon emissions. In 2013, the environmental researcher and activist, Bill McKibben (quoting a Climate Council of Australia report), wrote that Australia's projected coal exports would soon "produce $30 \%$ of the carbon needed to push global warming beyond two degrees" (McKibben, 2013, p. 7). He concluded that by as early as 2020 "the country's coal burnt abroad [as an export mineral] will be producing three times as much $\mathrm{CO} 2$ as all the country's cars and factories and homes" (McKibben, 2013, p. 7). The policy appears to make little economic sense, considering that in 2015 the global price of coal is two-thirds below the peak price of 2011. The market outcome appears grim for the industry: "dedicated coal producers in Australia like New Hope and Whitehaven have seen their market value slashed by $70-80 \%$ over the past five years" (Cleary, 2015, p. 24). It may though make shortterm (and short-sighted) political sense, as both the current government and the Labor Opposition are aware that mining generally, and coal in particular, is largely conducted in "swing" or conservative electorates. The long-term cost of electoral expediency will be high:

Ultimately, Australian state power has been sacrificed to the power of a single, polluting, damaging, dying industry, at the cost of every basic task of the modern state. This cannot last. (Schlosberg, 2015, p. 11) 
Many of the same conservative political electorates are also home to Indigenous communities who regularly negotiate mining agreements, although negotiation in most cases must be understood as a limited concept. If a mining venture is opposed by Indigenous people, but supported by government, mining takes precedent over Indigenous property rights, even when land is "protected" by the Native Title Act 1993-Cwlth (Altman, 2009, p.18). While mining is promoted as the economic saviour of Indigenous communities by mining companies themselves, government, and occasional Indigenous spokespeople, the issue is complicated, as the long-term advantages of mining as a means of delivering economic empowerment is questionable:

The value of the minerals sector to Australian prosperity is in stark contrast to the economic poverty experienced by many Indigenous Australians....Indigenous poverty, however, appears to be only minimally ameliorated by such agreements. (Scambary, 2013, p. 1)

In an extensive study of the history of mining in Australia and its relationship to Indigenous communities, Benedict Scambary found that negotiated agreements between Indigenous communities and mining companies "favour mainstream economic development", often at the expense of Indigenous communities. Relationships remained "fraught" while "mining agreements of themselves are not creating sustainable economic futures for Indigenous people" (Scambary, 2013, pp. 231-232). The economic pact between government and mining companies also comes at the expense and self-determination and autonomy within Indigenous communities:

The Australian state-that is committed to economic liberalism in such processes - seems to voraciously pursuing a strategy to further disempower Indigenous people in an extremely uneven power relationship. (Altman, 2009, p.18)

Combined concerns over climate change and the inequities embedded in historical relationships between Indigenous communities and mining companies has mobilized a new generation of Indigenous activists. Amelia Telford, a Bundjalung woman (referring to her Indigenous nation and Country), was recently announced at the Young Conservationist of the Year by the Australian Geographic Society (Cormack, 2015). She is also a member of both the Australian Youth Climate Coalition, and SEED, an Indigenous-led environmental organization she co-founded. Telford, a "self-identified greenie" points to the relationship between mining companies and Indigenous communities to support her additional concerns about climate change. "The fossil fuel industry", she writes, "has been putting stress on Aboriginal land, culture and communities for decades", with a poor record in not only environmental maintenance, but in failing to deliver genuine social and economic benefits to Indigenous communities (Telford, 2014, p. 1).

Indigenous activists are concerned that communities will become economically and culturally disadvantaged further if the desire for fossil fuel extraction in Australia continues unabated (which appears to be the clear policy of the current government-Feik, 2015). Government support of the mining industry has also historically restricted Indigenous access to traditional lands, including vital totemic and sacred sites (Altman, 2009 , p. 24). As an outcome of Australia's most recent mining 'boom' in Australia, Indigenous people are again being extracted from Country (Green, 2014; McQuire, 2015). Relationships between government and mining companies can produce adverse outcome for Indigenous communities opposing mining when "the state operates as a "broker state'", negotiating and, where necessary, legislating for the benefit of mining at the expense of Indigenous people (Altman, 2009, p. 5).

Successful mining applications in Western Australia have been dependent on the deregistration of a sacred sites (Garty, 2015), a situation that can not occur without legislative support from government. An expert in Human Geography at Curtin University in Western Australia, Todd Jones, estimates that 'more than 3,000 Aboriginal sites have lost registration status' in recent years (Jones, 2015), including many sites deemed necessary for protection against mining under the Aboriginal Heritage Act, first legislated in 1972 (Laurie, 2015). Meanwhile, in Queensland, the state Labor government is currently preparing to extinguish Native Title altogether to ensure that the proposed Carmichael coal mine can proceed without threat of a successful legal challenge by Indigenous groups (Australian Broadcasting Commission, 2015).

The potential economic benefit in the form of employment and mining royalty payments, as an outcome of mining are tempting, even with sacred Country itself under threat. Royalties are often promoted to Indigenous communities as the only means of material survival. The potential for royalties and other benefits are also negotiated between Indigenous groups and mining companies on an unequal playing field, as the "substantial structural power and resource imbalances disadvantage the Aboriginal parties in negotiations" (Martin, 2009, p. 100). When communities do choose mining, choice becomes a relative concept:

The absence of support for alternative livelihood options has contributed too, with Indigenous communities often facing the choice between mining or welfare dependence-and increasingly even welfare is being withdrawn if the mining option is not taken up. (Altman, 2009, p. 18) 
Some communities caught in such a bind are classed as "remote" within Australia, although the description has no cultural meaning in an Indigenous sense. In 2007 the John Howard led conservative government announced an "intervention" into the Northern Territory (where it has legal jurisdiction), a policy shift that resulted in enforced levels of social and economic control of Indigenous communities. (For a discussion of the Intervention and its aftermath see Scott \& Heiss, 2015). Not only was the Intervention dependent on the demonization of Indigenous communities in the media, the Commonwealth was required to suspect the Racial Discrimination Act (RDA) in order for it to discriminate directly against Indigenous people. (See McMullen, 2015, for an informed summary).

The Indigenous legal scholar, Professor Larissa Behrendt reminds that what the Commonwealth government described as a "national emergency" was the outcome of the neglect of the same Indigenous communities for over thirty years (Behrendt, 2015, p. 64). State and Commonwealth governments had previously been made aware of a greater need for the care of Indigenous children through major reports researched and produced by Indigenous scholars (Graham, 2015). The Northern Territory Intervention has impacted beyond the Northern Territory. If it is historically that case that 'even who and what Aboriginal people consider themselves to be has been affected by the representations of Aboriginality by others (Merlan, quoted in Martin, 2009, p. 113) then the Intervention has produced a nationwide definition of Indigenous inadequacy, and calls for a return paternalistic controls by the state. Indigenous communities across Australia have been neglected by successive state and Commonwealth governments, leaving the communities with little or non-existent economic and cultural autonomy whenever mining leases are being negotiated (Scambary, 2013).

The complexities faced by a desperate community, having to consider cash-over-Country, produce damaging tensions. A recent dispute involving a proposed gasmining leases being granted at James Price Point, near Broome in Western Australia, highlighted the struggles faced by Indigenous people making decisions about the viability of community. The site of the proposed venture, on Goolarabooloo land, caused a rift between those who believe the mine would "deliver economic benefits that would secure the welfare of future generations" and others in the community who argued that Indigenous people should not be forced to make a choice between cultural and socio/economic worth; "health, education and welfare service are a basic right for all Australians and should not be contingent upon giving up one's land and culture" (Muir, 2012, p. 6). Amongst those opposing the gas mine, "senior Goolarabooloo Traditional Owners categorically state that it [the proposed mine] is a deal that cannot be done since their responsibility is to care for that country for future generations" (Muir, 2012, p. 6).

It is rarely appreciated by the wider Australian community that Indigenous people confront burdensome layers of responsibility when considering the broad consequences of a proposed mining lease. An onerous cultural weight accompanies the consideration of the sacred-spiritual aspects of Country on the one hand, and the potential economic benefit to be gained in agreeing to mining on the other. When Indigenous traditional owners make important decisions regarding protection and maintenance of Country, they do so under duress, considering that their people are often suffering immediate and endemic social and economic disadvantage. The extraction of fossil fuels from Indigenous land ultimately becomes a major contributor to global warming. A policy initiative that would engage with Indigenous people more ethically and equally would be to materially reward communities for their continued protection of Country at the expense of environmentally harmful forms of mining. It makes economic and environmental sense, in addition to recognizing the rights of Indigenous people, that communities be materially compensated when they reach decisions based upon the spiritual and cultural value of Country. Rather than suffer further disadvantage for protecting the environment (thus producing a net benefit for the global community), Indigenous communities should be rewarded as means of securing an economic and cultural future.

\section{Two-Way Learning?}

Prior to the arrival of the British in Australia approximately $\mathbf{3 0 0}$ Indigenous nations co-existed for at least 50,000 years "dealing with climate and ecosystem change" (Green \& Minchen, 2014, p. 1). Intricate levels of knowledge of both the environment and related cosmologies continue to be held within Indigenous communities, including the consequences of the sea rise that occurred at the end of the Ice Age, between 8 to 10,000 years ago (Nunn \& Reid, 2015; Upton, 2015); the relationship between Indigenous storytelling, knowledge retention and astronomy (Hamacher, 2014); and the scientific methodology underpinning firestick farming, sustainable forms of hunting, care for Country, and traditional agricultural and fishing techniques (Gammage, 2011; Pascoe, 2014; Presland, 2008). A gradual engagement with the richness of such knowledge is creating partnerships between Indigenous people, the scientific and broader intellectual community, in realization of the potential of such knowledge.

Through modes of intellectual practice Indigenous people offer other societies the opportunity to better engage with the current manifestation of climate change in innovative ways. There is also an associated 
moral imperative at stake (Broome, 2012; Klein, 2014; Shue, 2014), as threats to the wellbeing and livelihood of Indigenous communities undermine the vitality and survival of communities themselves. Important cultural knowledge could also be lost, undermining the potential of future intellectual relationships between Indigenous and non-Indigenous society (Bird Rose, 2004). Whether through the degrading of Indigenous sacred and educational sites as an outcome of mining (discussed above), the wanton vandalism of sacred sites (Birch, 2010), or additional forced closures of, and government 'interventions' in Indigenous communities (Scott \& Heiss, 2015), the destruction of physical, ephemeral and spiritual culture denies Indigenous people access to ongoing customary practice. A responsibility to Country forms the basis of a dynamic and everevolving engagement with land and whatever changes may be required to adapt to shifts in the local ecology.

Both within Australia, and globally, Indigenous communities have a key role to play in adapting to climate change (Asia Indigenous Peoples Pact [AIPP], 2015; Chief, Daigle, Lynn, \& Whyte, 2014; Green, Niall, \& Morrison, 2012). The discipline of Anthropology, sometimes positioned as the enemy of Indigenous communities (Cowlishaw, 2015), has increasingly recognized the intellectual value of exploring concepts such as deep-time archaeology and climate ethnography within Indigenous communities. The potential benefits to communities beyond Indigenous peoples may substantial, such as an attempt to "re-situate the human in ecological terms... within an Indigenous philosophical ecology" (Bird Rose, 2005, p. 295). Researchers are also currently exploring the degree to which "place-based peoples observe, perceive and respond to the local effects of global climate change", enriching localized knowledge systems best equipped to deal with ecological shifts as an outcome of climate change (Crate, 2011, p. 179). Engaging with Indigenous people more directly and inclusively also provides community members the opportunity to voice concerns about the multitude of threats to health and wellbeing that climate change presents (Green, Niall, \& Morrison, 2012).

If relationships between Indigenous and nonIndigenous communities are to prosper the repository of intellectual wealth held by Indigenous people must be engaged with in an equitable manner, rather than it become an exercise in "cherry-picking" by outside experts with little understanding and respect for the potential of a genuine exchange, such as through the concept of "two-way leaning" (Muller, 2015). Whether assessing general wellbeing, connection to country, knowledge of ecology, the environment and climate, storytelling - the production of a culturally instructive narrative-is central to the maintenance and dissemination of Indigenous knowledge (Sakakibara, 2009). It is also an example of the holistic philosophies binding Indigenous people to country:
Many traditional owners express their attachment to country through their unique ecologies, and the discipline of ecology's focus on relationships links to the holistic language of country. (Weir, 2015, p. 1)

In the absence of an ethical framework able to facilitate productive relationships, the outcome for Indigenous people will most often be of negative value. The "intersubjective exchange", the working relationship, enacted within an unstated social contract- "you recognise my worth, I recognise yours"-has been described by one activist/researcher as an exercise in "moral reciprocity" (Vincent, 2012, p. 2). An important and cautionary caveat hovering over such exchanges is that Indigenous knowledge cannot be sifted through by outsiders for choice: "Indigenous knowledge is not simply a collection of facts, but a way of life" (Muller, 2015, p. 59). And while Traditional Ecological Knowledge (TEK) is increasingly valued by researchers, it has also become something of a "buzzword". Indigenous scholars in North America, for example, have noted that the wealthy, including some in the environmental movement, selectively covet aspects of TEK "to solve their own crises":

When our knowledge becomes a commodity it can be used at will by the power structures of the dominant society to support existing doctrines and the status quo. It can be appropriated, marginalized and even used against us. (Simpson, 2001)

Unfortunately, others within the scientific, economic and environmental bodies continue to have little interest in either TEK or the potential benefits of two-way knowledge exchanges. While Indigenous traditions remain "of little value in a world based on the oppression of whole nations of people and the destructive exploitation of natural resources" (Wilson, 2004, p. 360) these attitudes will prevail in some quarters, while Indigenous people will continue to be treated as "passive and helpless at best, and obstructionist and destructive at worse ... in contemporary discussion of development, conservation, indigenous rights and indigenous knowledge" (Salick \& Byg, 2007, p. 4). Such narrowminded thinking refuses to engage with the potential value offered by TEK. Human society has experienced changes in climate in the past, and the planet has periodically been confronted with catastrophic change to both the ecology and human and nonhuman life. Indigenous communities have been at the forefront of dealing with, and adapting to climate change in the past, offering an opportunity to face the challenge of contemporary climate change in innovative ways:

Indigenous peoples interpret and react to climate change impacts in creative ways, drawing on traditional knowledge as we as new technologies to find 
solutions, which may help society at large to cope with impending change. (Salick \& Byg, 2007, p. 4)

In Australia Indigenous communities are experiencing the impacts of climate change, in the form of bush-fires and drought in some areas of the country, and "warming temperatures, sea level rise, different rain patterns [and] more and stronger cyclones, floods and storms" in others (Stacy \& Tran, 2013, p. 5). Some communities, due to their isolated location, are affected by dramatic weather events to a degree that most communities experience only rarely (Tran et al., 2013). With infrastructure being poor in many Indigenous communities, including an absence of decent drainage, proper emergency shelters, inadequate transport and roads and a lack of suitable medical facilities, the health, social and economic aftershocks of an extreme weather events devastate communities in both immediately and long-term. To suggest that these communities are subsequently neglected by government is no overstatement. Following the severe floods in the Northern Territory in early 2015, one journalist was left asking the question, "Why don't Australians care about the lives of Aboriginal people?" when it was revealed that Indigenous communities had been the last to be offered shelter during the flood, and were forced to wait for a longer period of time to have the damage caused by the flood repaired (Sinclair, 2015, p. 1).

\section{Conclusion}

Researchers in Indigenous wellbeing conclude that for communities to be equitably engaged in future a holistic approach toward climate change must be implemented within both environmental and health policies. If this does not occur the socio-health and economic gap between Indigenous and non-Indigenous people in Australia will certainly widen (Green \& Minchen, 2014). Additionally, if relevant institutions, including government, fail to engage with Indigenous people, climate change policy initiatives remain inadequate. The wellbeing of Indigenous people in Australia is depended on the maintenance and care of Country. White Australia must give greater recognition to this need. In return, through the process of genuine exchange it could become the beneficiary of a new way of seeing. New ideas, dialogues and relationships present a challenge beyond a shift in economic and environmental thinking and innovative policy-making. Deborah Bird Rose believes that White Australia is suffering an "ethical paralysis" with regard to both the environment and relationships with Indigenous communities (Bird Rose, 2013 , p. 2). She offers an alternative strategy of communication, a dialogue of openness, rich with both risk and benefit:

To be open is to hold one's self available to others: one takes risks and becomes vulnerable. But this is also a fertile stance: one's own ground can become destabilized. In open dialogue one holds oneself available to be surprised, to be challenged and be changed. (Bird Rose, 2015, p. 128)

An expectation of an informed engagement on climate change with Indigenous communities is being voiced globally. For instance, In Aotearoa (New Zealand) Maori have called for not only recognition of traditional knowledge, but a participatory role in approaches and policies devised to deal with environmental policy generally and climate change specifically (Jones, Bennett, Keating, \& Blaiklock, 2014). It is a role that necessitates due recognition of Maori not only as First Peoples, but the holders of first knowledge. In northern America, particularly in Canada, where TEK is taught within both Indigenous communities and the academic classroom. A call for the formal recognition of TEK by Indigenous scholars, activists, and communities is accompanied by understandable hesitancy and concern, not least of all due to the structural and governmental contradictions that simultaneously debilitate Indigenous communities.

The Canadian experience offers a cautionary tale for Indigenous people globally, particularly in Australia, where social and economic disadvantage often mirror the North American experience. The Canadian Indigenous scholar, Waziyatawin Angela Wilson, commented a decade ago that 'before knowledge of these ways of being and interacting with the world can be shared...we must first work on recovering these traditions among our own populations' (Wilson, 2004, pp. 361-362). A second Indigenous scholar from Canada, Leanne Simpson warms that collaboration with outsiders can result in the dilution of TEK, undermining its original objective as an anti-colonial strategy:

The depoliticizing of Indigenous Peoples and TEK serves to make the discussion of TEK more palatable to scientists by sanitizing it of the ugliness of colonization and injustice, so scientists can potentially engage with the knowledge but not the people who own and live that knowledge (Simpson, 2004, p. 376).

The shift in mindset required to produce meaningful and valuable interactions between Indigenous and non-Indigenous people in Australia is perhaps the ultimate challenge to the nation. Key thinkers in the area, such as Bird Rose, ask that non-Indigenous people begin a conversation that respects Indigenous selfdetermination while considering the value of relationships built on "connection" rather than "unity" (Bird Rose, 2013, p.5). An additional shift in the individual and collective psyche in Australia is also needed if the impacts of climate change are to be mitigated. From a philosophical and intellectual perspective, "we need to 
spark our moral imagination" (Klein, \& Cave, 2015, p. $5)$. Serious climate action in Australia will continue to be piece-meal, fragmented and subject to unstable political whims in the absence of a fundamental shift in our relationship with the both each other and the environment.

\section{Acknowledgments}

I wish to recognize my appreciation of discussions that have assisted me greatly in completing this essay. My thanks, therefore, go to Sara Wills, Chris Healy, Stephen Muecke, Deborah Bird Rose and Michael Davis.

\section{Conflict of Interests}

The author declares no conflict of interests.

\section{References}

Alexander, C., Bynum, N., Johnson, E., King, U., Mustonen, T., Neofotis, P., . . . Weeks, B. (2011). Linking indigenous and scientific knowledge of climate change. BioScience, Vol. 61 No 6, 477-484.

Altman, J. (2009). Indigenous communities, miners and the state in Australia. In J. Altman \& D. Martin (Eds.), Power, culture, economy: Indigenous Australians and mining (pp. 17-49). Canberra: ANU e press.

Altman, J., \& Martin, D. (Eds.). (2009). Power, culture, economy: Indigenous Australians and mining (pp. 17-49). Canberra: ANU e press.

Asia Indigenous Peoples Pact. (2015). Asia Report and Indigenous Peoples. AIPP Printing Press Co.

Australian Broadcasting Commission. (2015). Carmichael coal mine: Coordinator-general proposes extinguishing native title over key mining property. Retrieved from www.abc.net.au/news

Australian Government. (2015a). Energy white paper. Canberra: Department of Industry and Science. Retrieved from ewp.industry.gov.au

Australian Government. (2015b). 2015 intergenerational report. Canberra: The Treasury. Retrieved from www.treasury.gov.au

Behrendt, L. (2015). The dialogue of intervention. In R. Scott \& A. Heiss (Eds.), The intervention: An anthology (pp. 64-74). Salisbury South: Griffen Press.

Birch, T. (2010). Nothing has changed: The making and unmaking of Koori culture. In Meanjin anthology (pp. 107-118). Melbourne. Melbourne University Press.

Bird Rose, D. (2004). Reports from a wild country. Kensington: University of New South Wales Press.

Bird Rose, D. (2005). An indigenous philosophical ecology: Situating the human. The Australian Journal of Anthropology, 16(3), 294-305.

Bird Rose, D. (2013). Slowly-Writing into the Anthropocene. TEXT, 20, 1-14.
Bird Rose, D. (2015). Dialogue. In K. Gibson, D. Bird Rose, \& R. Fincher (Eds.), Manifesto for living in the Anthropocene (pp. 271-273). Brooklyn: Punctum Books.

Broome, J. (2012). Climate matters: Ethics in a warming world. New York: W.W. Norton and Company.

Chief, K., Daigle, J., Lynn, K., \& Whyte, K. P. (2014). Indigenous experiences in the U.S. with climate change and environmental stewardship in the Anthropocene. In USDA Forest Service (RMRS-P-71, pp. 161-176). Washington: USDA Forest Service.

Christoff, P. (Ed.). (2014). Four degrees of global warming: Australia in a hot world. London: Routledge.

Cleary, P. (2015). Coal crash: What it means for Australia. The Monthly.

Coorey, P. (2015). UN Climate Conference 2015: Revolt sparks backdown on fossil fuel phase out. Retrieved from www.afr.com

Cormack, L. (2015). Young conservationist of the year. Retrieved from http://www.smh.com.au

Cowlishaw, G. (2015). Friend or foe? Anthropology's encounter with aborigines. Inside Story. Retrieved from http://insidestory.org.au

Cox, L. (2015). Energy paper "willfully deluded" on climate change. Age. Retrieved from www.theage. com.au

Crate, S. (2011). Climate and Culture: Anthropology in the Era of Contemporary Climate Change. Annual Review of Anthropology, 40, 175-194.

Davey, M. (2015). Australia "public enemy number one" of UN climate talks, says Nobel laureate. The Guardian. Retrieved from www.theguardian.com

Degawan, M., \& Krupnik, I. (2011). Indigenous peoples, marginalized populations and climate change: Vulnerability, adaptation and traditional knowledge. Workshop proceedings, 19-21 July 2011, Mexico City, Mexico.

Feik, N. (2015). Dishonesty is the worst policy. The Monthly Blogs. Retrieved from www.themonthly. com

Gammage, B. (2011). The biggest estate on earth: How aborigines made Australia. Crows Nest: Allen \& Unwin.

Garty, L. (2015). Traditional owners in WA to launch class action over deregistration of sacred sites. Retrieved from www.abc.net.au

Georgatos, G. (2015). Quality of life for Australians 2nd only to Norway, but for First Peoples 132nd. The Stringer. Retrieved from http://thestringer.com.au

Graham, C. (2015). Bad aunty: seven years on, how $A B C$ lateline sparked the racist NT intervention. Retrieved from http://newmatilda.com

Green, K. (2014). Bringing social justice in from the cold as we get closer to a global climate change deal. The Conversation. Retrieved from www.theconver sation.com

Green, D., \& Minchen, L. (2014). Living on climate- 
change country: Indigenous health, well-being and climate change in remote Australian communities. EcoHealth, 11, 1-10.

Green, D., King, U., \& Morrison, J. (2009). Disproportionate burdens: the multidimensional impacts of climate change on the health of indigenous Australians. The Medical Journal of Australia, 190(1), 1-3.

Green, D., Niall, S., \& Morrison, J. (2012). Bridging the gap between theory and practice in climate change vulnerability assessments for remote Indigenous communities in northern Australia. Local Environment: the International Journal of Justice and Sustainability, 17(3), 295-315.

Grigg, A. (2015). BHP and Rio Tinto are quietly exiting coal. Retrieved from www.afr.com

Climate talks: Anger over removal of human rights reference from final draft. (2015, December 11). Guardian.

Hamacher, D. (2014). Stories from the sky: astronomy in Indigenous knowledge. The Conversation. Retrieved from www.theconversation.com

Hamilton, C. (2013). Earth masters: Playing God with the climate. Crows Nest: Allen \& Unwin.

Jerolmack, C. (2014). Choking on poverty: Inequality and environmental suffering. Public Books. Retrieved from www.publicbooks.org

Jones, T. (2015). Separate but unequal: the sad fate of Aboriginal heritage in Western Australia. Retrieved from http://theconversation.com

Jones, R., Bennett, H., Keating, G., \& Blaiklock, A. (2014). Climate change and the right to health for Maori in Aotearoa/New Zealand. Health and Human Rights Journal, 16(1).

Klein, N. (2014). This changes everything: capitalism vs. the climate. London: Allen Lane.

Klein, S., \& Cave, S. (2015). Once and future sins. Aeon Magazine, pp. 1-15. Retrieved from http://aeon.co/ magazine

Kolbert, E. (2014). The sixth extinction: An unnatural history. London: Bloomsbury.

Laurie, V. (2015, September 25). Ancient aboriginal sites at risk in the Pilbara. The Australian.

Lewis, S. L., \& Maslin, M. A. (2015). Defining the Anthropocene. Nature, 519, 171-180.

Martin, D. F. (2009). The governance of agreements between aboriginal people and resource developers: Principles for sustainability. In J. Altman \& D. Martin (Eds.), Power, culture, economy: Indigenous Australians and mining (pp. 99-126). Canberra: ANU e press.

McKibben, B. (2013). How Australian coal is causing global damage. The Monthly, June, pp. 1-12.

McMullen, J. (2015). Rolling thunder: Voices against oppression. In R. Scott \& A. Heiss (Eds.), The intervention: An anthology (pp. 115-138). Salisbury South: Griffen Press.

McQuire, A. (2015). WA government deregisters world's oldest rock art collection as sacred site. Retrieved from http://newmatilda.com

Muir, K. (2012). Politics, protest and performativity: The broome community's 'no gas on the Kimberley coast' campaign. Australian Humanities Review, 53, 1-17.

Muir, C. (2014). The broken promise of agricultural progress: An environmental history. London: Routledge.

Muller, S. (2015). 'Two ways': Bringing indigenous and non-indigenous knowledge together. In J. K. Weir (Ed.), Country, native title and ecology (pp. 59-79). Canberra: ANU e-press.

Nixon, R. (2011). Slow violence and the environmentalism of the poor. Cambridge: Harvard University Press.

Nunn, P., \& Reid, J. (2015). Aboriginal memories of inundation of the Australian coast dating from more than 7000 years ago. Australian Geographer, 47(1), 11-47.

Pascoe, B. (2014). Dark emu: Black seeds agriculture or accident. Broome: Magabala Books.

Presland, G. (2008). The place for a village: How nature has shaped the city of Melbourne. Melbourne: Museum Victoria.

Prystupa, M. (2015). Trudeau fights to keep Indigenous rights in Paris climate deal. Retrieved from http://nationalobserver.com

Sakakibara, C. (2009). Speaking of place: Contemporary Inupiat storytelling and place-making in the time of climate change. In INALCO 2009, Proceedings of the $15^{\text {th }}$ Inuit Studies Conference, Orality (pp. 1-9).

Salick, J., \& Byg, A. (2007). Indigenous people and climate change. Oxford: Tyndall Centre for Climate Change Research.

Scambary, B. (2013). My country, mine country: Indigenous people, mining and development contestation in Australia. Canberra: ANU e-press.

Schlosberg, D. (2015). Sabotage: How the attack on renewables undermines government. Australian Book Review. Retrieved from www.australianbookreview. com.au

Scott, R., \& Heiss, A. (Eds.). (2015). The intervention: An anthology. Salisbury South: Griffen Press.

Shue, H. (2014). Climate justice: Vulnerability and protection. Oxford: Oxford University Press.

Simpson, L. (2001). Aboriginal peoples and knowledge: Decolonizing our processes. The Canadian Journal of Native Studies, XXI, 137-148.

Simpson, L. (2004). Anticolonial strategies for the recovery and maintenance of indigenous knowledge. American Indian Quarterly, 28(3/4), 373-385.

Sinclair, C. (2015). Australian cyclone ignores Aboriginal people in remote areas. Retrieved from www.nt news.com.au

Stacy, C., \& Tran, T. (2013). Climate change adaptation on Karajarri Country-Community report. Canberra: 
Australian Institute of Aboriginal and Torres Strait Islander Studies.

Steffen, W. (2015). Quantifying the impact of climate change on extreme heat in Australia. Potts Point: Climate Council of Australia.

Taylor, L. (2015a). Australia's climate change "debate" all talk and no action. The Guardian. Retrieved from www.theguardian.com

Taylor, L. (2015b). Prominent Australians ask world leaders to consider ban on new coalmines. The Guardian. Retrieved from www.theguardian.com

Telford, A. (2014). Climate change is the biggest threat to black Australia. New Matilda. Retrieved from https://newmatilda.com

Tran, T., Strelein, L., Weir, J., Stacy, C., \& Dwyer, A. (2013). Changes to country and culture, changes to climate: Strengthening institutions for indigenous resilience and adaptation. Canberra: Australian Institute of Aboriginal and Torres Strait Islander Studies.
Union of Concerned Scientists. (2005). How coal works. Retrieved from www.ucsusa.org

United Nations. (2013). World happiness report 2013. New York: UN.

Upton, J. (2015). Ancient sea rise tale told accurately for 10,000 years. Scientific American. Retrieved from www.scientificamerican.com

Van Neerven, E. (2015). The country is like a body. Right Now, pp. 1-8.

Vincent, E. (2012). 'Hosts and Guests: Interpreting Rockhole Recovery Trips', Australian Humanities Review, 53, pp. 1-9. Retrieved from www.australian humanitiesreview.org

Weir, J. K. (2015). Country, native title and ecology (pp. 1-19). Canberra: ANU e press.

Weizman, E., \& Sheikh, F. (2015). The conflict shoreline. Göttingen: Steidl.

Wilson, W. A. (2004). Indigenous knowledge recovery is indigenous empowerment. American Indian Quarterly, 28(3/4), 359-372.

\section{About the Author}

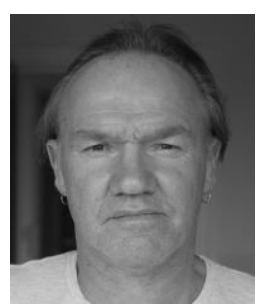

\section{Dr. Tony Birch}

Tony Birch is the inaugural Bruce MacGuinness Research Fellow in the Moondani Academic Unit at Victoria University, in Melbourne Australia. He is both a researcher and fiction writer. His books include Shadowboxing (2006), Father's Day (2009), Blood (2011), The Promise (2014) and Ghost River (2015). 